\title{
Development features of the Russian higher education system in present-day conditions
}

\author{
Maksim V. Yakovlev ${ }^{*}$, Eduard S. Gareev ${ }^{2}$,Emil R. Burangulov ${ }^{2}$, Nika E. Valitova ${ }^{2}$, and \\ Maria E. Ivanova ${ }^{2}$ \\ ${ }^{1}$ Lomonosov Moscow State University, Department of Philosophy of Politics and Law of the Faculty \\ of Philosophy, Moscow, Russia \\ ${ }^{2}$ Ufa State Petroleum Technological University, Institute of Oil and Gas Business, Department of \\ Social and Political Communications, Ufa, Russia
}

\begin{abstract}
Based on research material, the authors of the present article determine and critically comprehend the problems and specifics of the Russian higher education development in the current context. It is concluded that the global trends of digitalization, internationalization, commercialization, as well as the internal circumstances of the Russian reality (administrative pressure, economic decline, etc.), have significantly changed the Russian higher education system and caused difficulties in its development (narrow departmental nature of educational policy, shifting the focus on the qualitative content of fundamental education to the wayside, etc.). In order to solve the noted problems, it is proposed to use the theoretical and practical developments of the issues concerning the education content and form of the most prominent Russian researchers (N.A. Berdyaev, S.N. Bulgakov, M.O. Gershenzon, S.L. Frank, etc.), and to implement methods of a constructive combination of the classical university strategy and commercialization, focused on the interests of society and science.
\end{abstract}

Keywords: academic capitalism, higher education, internationalization, educational services, digitalization.

\section{Introduction}

The scientific study of the current status of education in all epochs among different peoples can be confidently attributed to the kind of dramatic aspect, bearing in mind the acute conflict of the plots and the inevitable emotionality. As early as in 1845, Victor Hugo, through the hero of his novel "Les Miserables", Combeferre, feared that "the present poverty of method, the paltriness from a literary point of view $<\ldots>$ the tyrannical dogmatism of official pedants, scholastic prejudices and routines should end by converting our colleges into artificial oyster beds" [1].

Today, 175 years later, society is facing the same problems, but the situation has worsened due to, as M. Weber would say, the unintended consequences of those ideas and decisions that previously seemed a good way out and were aimed at overcoming difficulties in the

\footnotetext{
* Corresponding author: maxvuz@mail.ru
} 
development of social institutions. The focus on profit-making has become one of the main strategies of today's higher educational institutions, which is also promoted by internationalization and digitalization.

\section{Methods}

In January 2019, an expert survey was conducted in nine Russian regions of the Volga Federal District. Thirty-four employees of the higher education sector answered questions about the status of Russian higher education in the current context. The survey was conducted on condition of anonymity.

In December 2018, 220 students of the Bashkir State Pedagogical University named after M. Akmulla (BSPU) and Ufa State Petroleum Technological University (USPTU) were surveyed to identify the specifics of the respondents' behavior and preferences.

In March 2018, three focus groups were held to consider the possibilities of attracting foreign students and the development factors of the Russian higher education, which were attended by 20 associates of universities and colleges, ministries, and departments of Russia.

\section{Results}

During the discussions, held within the framework of the focus group, the participants noted that today the Russian higher school can be considered by and large as an auxiliary structure, which is designed to serve the current tasks of the economy to train highly targeted personnel from a relatively small number of citizens within the framework of a narrow departmental educational policy. The latter is generally characterized by a course on building a "vertical of universities", a focus on a controversial competence approach (in the form, in which it was comprehended by the Russian recipients of the original ideas of N. Chomsky, J. Raven, etc.), as well as by a focus on purely quantitative indicators of the teaching staff activities without taking into account the quality and content of the work performed, which forces teachers to conduct formally a huge number of class sessions and to use special techniques (using sometimes manipulations) to increase the citation indices, Hirsch index, etc.

A survey of students conducted in December 2018, confirmed the declining trend in the social status of teachers and higher education among students.

The expert survey complements and expands the presented picture. More than half of the experts defined the role of Russian higher education in the contemporary socio-political process as low $(54.2 \%)$.

The main problems of contemporary Russian higher education, identified in the course of the survey, were shifting away from national traditions of higher education and rejecting prior experience (32.1\%); entering into the Bologna Process $(24.9 \%)$; pressing from the government and state bureaucracy (15.4\%); moving of graduates to other countries $(12.8 \%)$; providing weak funding $(8.6 \%)$; noncompliance with the requirements of the Bologna Process $(4 \%)$. At that $2.2 \%$ of respondents found it difficult to answer.

Among the remaining (though gradually lost) advantages of Russian higher education, the respondents referred to the fundamental nature of training, relatively low cost (in comparison with universities in Western Europe and the USA), significant experience and potential in teaching natural sciences and mass specialties (doctors, engineers, etc.). 


\section{Discussion}

Considering the research results and drawing certain conclusions, one comes across a difficulty that is not easy to avoid - the gap between the classical vision of university education and the unswerving commercialization of higher education.

The authors proceed from the thesis of Wilhelm von Humboldt that higher educational institution "is nothing but the spiritual life of people whom their leisure or inner desire lead to science and research" [2]. In such an organization, professors, teachers, researchers, and students jointly serve society and science contributing to scientific progress according to the principles of universalism, collectivism, selflessness, and organized skepticism proclaimed by R. Merton [3]. However, today's realities have blurred the idea of the traditional mission of the university and contributed to the transition to a different paradigm - academic capitalism.

The creators of the concept of academic capitalism, S. Slaughter and L. Leslie, consider universities as commercial companies actively competing in the market, specializing in the provision of paid educational services, selling research and development results (licenses, patents), creating small enterprises, searching for grants, donations, and concluding trade contracts $[4,5]$. B. Clark proposed to call such structures entrepreneurial universities [6: 10].

Due to the expansion of academic capitalism with its demands for financial and economic efficiency, the composition and structure of university management are being transformed by transferring powers to technocratic managers. This is indicated, for example, by $\mathrm{G}$. Roggero, when analyzing the realities of Italian universities, which have now become very similar to commercial corporations [7: 88].

The authors of the article share the concerns of D. Dickson and colleagues, who underlines that the emphasis on profit making inevitably leads to the fact that universities change their disinterested search for new knowledge and classical development strategy, initially focused on social progress, and serve the owners of large capital and their economic needs [8: 17]. Besides, the digitalization of capitalist society leads to limited access to information, increased information control, and an increase in various types of information manipulations to the benefits of governments and corporations $[9,10]$, which reduces the public space and narrows the area of available and reliable information [11].

The resolution to the existing contradiction between the traditional vision of the university and capitalist expansion can be a constructive combination of the interests of society and science and the common trend of commercialization. A good example of this is given by O.H. Ylijoki, who convincingly shows how traditional values, socially significant practices, ideals, and norms of science and market orientation co-exist productively in several Finnish universities [12].

Some features of the state policy in higher education in Russia are noted in the studies of L.A. Zhuravleva, N.B. Kostin, T.V. Duran, L.V. Kostina, and K.V. Trofimov [13-16]. The role and tasks of public institutions in the implementation of state educational policy were pointed out by E. M. Kryukova, S.A. Krapotkina, and E.N. Egorova [17].

Features of foreign students' motivation and adaptation in Russia were revealed by I.A. Vershinina, A.R. Kurbanov, and N.A. Panich [18].

\section{Conclusion}

Based on the above, it can be concluded that the main features of the Russian higher education system development in the current context are the departmental nature of educational policy, the lack of development of projects in the field of higher education (like the competencebased approach), the loss of national traditions (fundamentality, specialist's programs, etc.), the need to meet the requirements of the Bologna Process, the decline in the status of higher 
education, focus on financial and economic efficiency and scientometrics without taking into account the quality and content of the work performed.

In the authors' opinion, to overcome noted difficulties, it is necessary to use the results of the complicated and long development of the optimal system of higher education in Russia, which was performed by outstanding representatives of Russian science (N.A. Berdyaev, S.N. Bulgakov, M.O. Gershenzon, S.L. Frank, etc.). These and other works can give competitive advantages to Russian higher education and a new impetus for its development. This concerns implementing unique cultural achievements into the format of Bologna Process, adopted in Russia, like it was done, for example, in Germany, which managed to preserve its centuries-old traditions of higher education in the new conditions. Only in the wake of this approach, one can craft an effective strategy for the development of Russian higher education - a strategy that would allow filling the format of the Bologna Process with national content which would include the integrated achievements and traditions of Russian higher education, taking into account the realities of academic capitalism and digitalization.

\section{References}

1. V. Hugo, Les Miserables, Vol, 3, Book 4 (BiblioBazaar, Charleston, 2009)

2. W. von Humboldt, Neprikosnovennyi Zapas, 2(22), 32-47 (2002).

3. R. Merton, The sociology of science (University of Chicago Press, Chicago, 1973)

4. G. Rhoades, S. Slaughter, Social Text 51(2), 9-38 (1997)

5. S. Slaughter, L. Leslie, Academic capitalism. Baltimore (The Johns Hopkins University Press, London, 1997)

6. B.R. Clark, Change: The Magazine of Higher Learning, 32(1), 10-19 (2000). https://doi.org/10.1080/00091380009602704

7. G. Roggero, Neprikosnovennyi zapas, 3(77), 88-102 (2011)

8. D. Dickson, The new politics of science (University of Chicago Press, Chicago, 1988)

9. M. Castells, The Internet galaxy. Reflections on the Internet, business and society (Oxford University Press, Oxford, 2001)

10. H. Schiller, The mind managers (Beacon Press, Boston, 1973)

11. J. Habermas, Moral consciousness and communicative action (John Wiley \& Sons, Hoboken, 2015)

12. O.H. Ylijoki, Higher Education, 45, 307-335 (2003). https://doi.org/10.1023/A:1022667923715

13. L.A. Zhuravleva, Central Russian Journal of Social Sciences, 11(3), 118-125 (2016). https://doi.org/10.737/20393

14. T.V. Duran, N.B. Kostina, Management Issues, 03(40), 124-132 (2016)

15. L.V. Kuznetsova, Journal of Public and Municipal Administration, 5(1), 49-52 (2016). https://doi.org/10.12737/18848

16. K.V. Trofimov, Vestnik Zabaykal'skogo Gosudarstvennogo Universiteta, 23(2), 86-94 (2017)

17. E.M. Kryukova, S.A. Krapotkina, E.N. Egorova, Aktual'nyye Problemy Rossiyskogo Zakonodatel'stva, 14, 61-64 (2016)

18. I.A. Vershinina, A.R. Kurbanov, N.A. Panich, Universitetskoe Upravlenie: Praktika i Analiz, 6, 94-102 (2016). https://doi.org/10.15826/umj.2016.106.063 